\title{
Öğretmen Yetiştirmede Etkileşimli Tahta Kullanımı: Bir Yıllık Deneyimli Akademisyen ve Öğretmen Adaylarının Görüşleri
}

\section{Interactive White Board Use in Teacher Training: Trainers vs. Trainees after One Year Experiences}

\author{
Çetin GÜLER ${ }^{* *} \quad$ Hayati ÇAVUş ${ }^{* * *}$
}

Received: 09 February 2018

Research Article

Accepted: 27 August 2018

ABSTRACT: The aim of this study is to determine the opinions of the teacher trainers and teacher trainees for the use of interactive white board technology in the teacher training process and to make suggestions for a more effective and efficient teacher training process by using the interactive white board in line with these opinions. Descriptive survey model was used in the study. Participants of the study consisted of 35 teaching trainers and 969 registered teacher trainees of the education faculty of a university in Anatolia in 2015. After one year experiences of the participants' with interactive white boards, data were collected about the experiences of both groups. It can be said that the interpretation of the data obtained from the teacher trainers and the teacher trainees after their experiences of using the interactive white board for one year is generally positive towards the use of interactive white boards in the educational process. It has been seen that teacher trainers mostly use interactive white boards to make presentations and are mostly disturbed by software and hardware problems with interactive white boards. It was concluded that both the teacher trainers and the teacher trainees did not see themselves adequately about the interactive white board use and they needed trainings in this regard, and suggestions were made to both practitioners and researchers in this direction.

Keywords: teacher training, use of IWB, teacher trainees, teacher trainers.

ÖZ: Bu çalışmanın amacı, öğretmen yetiştirme sürecinde etkileşimli tahta teknolojisin kullanımına yönelik öğretim elemanlarının ve öğretmen adaylarının görüşlerini belirlemek ve bu görüşler doğrultusunda etkileşimli tahta kullanımıyla daha etkili ve verimli bir öğretmen yetiştirme süreci için önerilerde bulunmaktır. Çalışmada betimsel tarama modeli kullanılmıştır. Çalışmanın örneklemi, 2015 yılında Anadolu'daki bir üniversitenin eğitim fakültesinde çalışmakta olan 35 öğretim elemanı ve kayıtlı 969 öğretmen adayından oluşmaktadır. Katılımcıların etkileşimli tahtalarla bir yıllık deneyimlerinin ardından, her iki grubun deneyimlerine yönelik veri toplanmıştır. Öğretim elemanlarının ve öğretmen adaylarının bir yıllık etkileşimli tahta kullanma deneyimleri sonrasında kendilerinden elde edilen verilerin çözümlenmesi sonucunda öğretim elemanlarının ve öğretmen adaylarının etkileşimli tahta ile ilgili görüşlerinin genel olarak olumlu olduğu söylenebilir. Öğretim elemanlarının etkileşimli tahtaları daha çok sunum yapmak için kullandıkları ve bu kullanımlarda daha çok etkileşimli tahtaların yazılımsal ve donanımsal sorunlarından rahatsız oldukları görülmüştür. Hem öğretim elemanlarının hem de öğretmen adaylarının etkileşimli tahta kullanımı konusunda kendilerini yeterli görmedikleri ve bu konuda eğitimlere ihtiyaçları olduğu sonucuna varılmış ve bu doğrultuda hem uygulayıcılara hem de araştırmacılara önerilerde bulunulmuştur.

Anahtar kelimeler: öğretmen yetiştirme, etkileşimli tahta kullanımı, öğretmen adayları, öğretim elemanları.

\footnotetext{
** Corresponding Author: Dr., Van Yüzüncü Y1l University, Van, Turkey, cetin@ yyu.edu.tr

${ }^{* * *}$ Assoc. Prof. Dr., Van Yüzüncü Y1l University, Van, Turkey, hcavus@ yyu.edu.tr
}

Citation Information

Tofur, S. (2018). Öğretmen yetiştirmede etkileşimli tahta kullanımı: Bir yıllık deneyimli akademisyen ve öğretmen adaylarının görüşleri. Kuramsal Eğitimbilim Dergisi [Journal of Theoretical Educational Science], 11(4), 838-859. 


\section{Giriş}

Eğitimsel süreç ve yaklaşımlar teknoloji gibi bazı etkenlere bağlı olarak değişim gösterebilmektedirler. Bu değişimler öğretmen yetiştirme süreçlerini de etkilemektedir. Özellikle teknolojideki değişimler ve bu değişimlerin eğitim alanına yansımaları bu tür değişimleri neredeyse zorunlu kılmaktadır (Al-Qirim, 2011). Özel ve kamu kurumları eğitim süreçlerini daha etkili ve verimli kılmak adına teknolojik yatırımlarda bulunmaktadırlar. $\mathrm{Bu}$ yatırımların amaçlarına yönelik etki ve farklılıklara yol açmalarının, uygun ve doğru kullanılmalarına bağlı olduğu söylenebilir. $\mathrm{Bu}$ tür teknolojilerin eğitim süreçlerinde uygun ve doğru kullanılmalarındaki önemli aktörlerden biri olarak öğretmenler değerlendirilebilir (Beauchamp \& Kennewell, 2012; Canbolat, 2011; Yüksel \& Adıgüzel, 2012). Öğretmenlerin doğru pedagojik yaklaşımlarla yeni teknolojileri sınıflarında kullanmaları bu süreçlerin amaçları doğrultusunda gerçekleşmesinde önemli bir etken olarak görülebilir (Badilla Quintana, 2012; Beauchamp \& Kennewell, 2012; Canbolat, 2011; Shulman, 1986; Sumak \& Sorgo, 2016; Yüksel \& Adigüzel, 2012). Bununla beraber yeni neslin teknoloji kullanımına yönelik ilgi ve becerileri öğretmenlerinin de onların eğitim sürecine etkin katılımlarını sağlamak (Ali \& Al-kaabi, 2012; Badilla Quintana, 2012; BruffaertsThomas \& Bruffaerts, 2013; Ipek \& Sözcü, 2016; Lopez \& Krockover, 2014; Tataroglu \& Erduran, 2010; Winzenried, Dalgarno \& Tinkler, 2010) adına yeterli düzeyde teknoloji kullanabilme yetisine sahip olmalarını gerektirdiği de söylenebilir (Akgün, 2013; Lai, 2014; Shulman, 1986). Ayrıca eğitim sürecinde teknoloji kullanımına yönelik öğretmen yetiştirme sürecine de dikkat çekilerek; teknolojiden beklenen yararın elde edilebilmesi için ögretmen adaylarının uygun teknolojileri uygun pedagojik yaklaşımlarla kullanabilecek ve bu yetilerini öğrencilerine de aktarabilecek şekilde yetiştirilmeleri gerektiği vurgulanmaktadır (Beauchamp \& Kennewell, 2012; Campbell \& Martin, 2010; Çelik \& Kahyaoğlu, 2007; Mishra \& Koehler, 2006; Schmidt vd., 2009; Sumak \& Sorgo, 2016; Winzenried vd., 2010).

Daha etkili eğitim ortamlarının sağlanabilmesi adına etkileşimli tahta (ET) gibi öğretim teknolojilerinin (Al-Qirim, 2011) eğitim ortamlarında kullanılması önemli görülmektedir (Akyüz, Pektaş, Kurnaz \& Memiş, 2014; Beauchamp \& Kennewell, 2012; Campbell \& Martin, 2010). ET, beyaz tahta, kara tahta ve bilgisayar teknolojilerinin birleşimi şeklinde düşünülüp; eğitim ortamlarının kalitesinin arttırılmasına yarar sağlayabilecek teknolojilerden biri olarak değerlendirilebilir (Jang \& Tsai, 2012a). Ancak teknolojinin tek başına eğitimde kaliteye katkı sağlayabileceğini iddia etmek doğru olmayacaktır (Šumak, Pušnik, Heričko \& Šorgo, 2017). Bir teknolojinin etkililiğinin ve verimliliğinin onu kullananların kullanımına bağlı olduğu söylenebilir. ET gibi teknolojilerin eğitim ortamlarında kullanımlarına yönelik olarak bu teknolojileri kullanacak olan öğretmenlerin niteliklerinin önem kazandığı söylenebilir (Al-Qirim, 2011; Badilla Quintana, 2012; Campbell \& Martin, 2010; Öztürk \& Horzum, 2011). Bu bağlamda öğretmenlerin hangi teknolojileri, pedagojik ve bağlamsal gereksinimler doğrultusunda nasıl kullandıklarının teknolojinin kendisinden daha önemli olduğu ifade edilebilir (Campbell \& Martin, 2010; Pamuk, Ülken \& Dilek, 2012). Öğretmenlerin kişisel gelişimlerinde kullanılabilecek yeni yöntem ve yaklaşımlar, sadece öğretmen gelişimine değil ayrıca öğrencilerin gelişimlerine de olumlu katkılar sağlayabilir (de Groot-Reuvekamp, Ros \& van Boxtel, 2018). 
Aralarında Türkiye'nin de bulunduğu bazı ülkeler (Al-Qirim, 2011; Beauchamp \& Kennewell, 2012; Bruffaerts-Thomas \& Bruffaerts, 2013; Turel, 2011) eğitim ve teknoloji ilişkisine oldukça önem vermekte ve hatırı sayılır ölçeklerde projelerle eğitimde teknolojiden yarar sağlamaya çalışmaktadır. Türkiye bu doğrultuda 2012 yılında "Fırsatları Arttırma ve Teknolojiyi İyileştirme Hareketi", kamuoyunda bilinen adıyla FATİH projesini başlatmıştır. Millî Eğitim Bakanlığının (MEB) ilgili biriminin resmî web sitesinde FATİH projesi ile ilgili "Her öğrencimizin en iyi ĕgitime kavuşması, en kaliteli eğitim içeriklerine ulaşması ve eğitimde firsat eşitliğinin sağlanması için tasarlanmış olan FATIH Projesi, ĕgitimde teknoloji kullanımıyla ilgili dünyada uygulamaya konulan en büyük ve en kapsamlı eğitim hareketidir." ifadesi yer almaktadır (MEB, 2017). FATİH projesi kapsamında Türkiye'de yer alan bütün ilkokul, ortaokul ve liselerin dersliklerine ET'lerin kurulması ve bu okullardaki bütün öğretmen ve öğrencilere tablet bilgisayar dağıtılması amaçlanmıştır. Proje 2017 yılı itibariyle devam etmekle beraber anılan donanımsal yatırımların yanı sıra bu donanımları destekleyecek yazılımlara da yer verilmektedir. Gerek donanımsal gerekse yazılımsal açıdan bu proje dünyadaki en büyük ve en kapsamlı hareketlerden biri olarak değerlendirilebilir. Diğer taraftan bu projede hedeflenen sonuçlara ulaşılması adına ögretmenlerin çok önemli bir rolünün olduğunu vurgulamakta yarar görülebilir. MEB, FATİH projesiyle birlikte sunulan teknolojilerden eğitim sürecinde etkili bir yararın sağlanması amacıyla, öğretmenlere proje kapsamına yönelik hizmet içi eğitim çalışmalarına yoğunluk vermiştir. Ancak Mart 2016'da MEB ilgili müdürlüğü tarafından gerçekleştirilen ve bu çalışmanın araştırmacılarından birinin de katıldığı bir toplantıda proje yürütücüsü konumundaki ilgili bir yöneticinin " $M E B$ bünyesinde ögretmen olarak atanan öğretmenlere yönelik çok ciddi hizmet içi eğitimler sunmamıza rağmen beklenen verimi alamiyoruz. Bu eğitimlerin, ögretmenlere hizmet öncesinde verilmiş olması çok daha etkili olurdu." ifadelerinin öğretmen yetiştirme sürecinde ET gibi teknolojilerin kullanılmasının önemine katkı sağlar nitelikte olduğu söylenebilir.

Araştırmanın yapıldığı, Anadolu'da yer alan bir üniversitenin eğitim fakültesi yetiştirmekte olduğu öğretmen adaylarını, öğretmen olduklarında, görece yeni sayılabilecek (Ali \& Al-kaabi, 2012; Šumak vd., 2017) bu teknolojileri uygun şekilde kullanabilecek nitelikte yetiştirebilmek amacıyla 2015 yılında bünyesindeki her anabilim dalının en az bir sınıfına ET kurdurmuştur. ET kurulumundan sonra öğretim elemanlarına ET kullanımına yönelik bir eğitim sunulmuştur. Ancak teknolojinin varlığ tek başına yeterli olmamaktadır (Šumak vd., 2017). Bu durum ve anılan alanyazında ifade edilen benzer durum ve öneriler doğrultusunda bu çalışmanın gerçekleştirilmesine karar verilmiştir. Bu çalışmanın amacı, öğretmen yetiştirme sürecinde ET teknolojisin kullanımına yönelik öğretim elemanlarının ve öğretmen adaylarının görüşlerinin belirlenmesi ve bu görüssler doğrultusunda ET kullanımıyla daha etkili ve verimli bir öğretmen yetiştirme süreci için önerilerde bulunmaktır.

Öğretmen yetiştirme sürecinde teknoloji kullanımının yeri ve önemi, anılan ifadelerden dolayı üzerinde çalışılması gereken bir alan olarak değerlendirilebilir. Öğretmen adaylarının, öğretmen olduklarında ET gibi teknolojileri sınıflarında doğru ve etkili kullanabilmelerinde, öğretmenlik eğitimleri sürecinde bu teknolojilerin öğretmen yetiştiricileri (akademisyenler) tarafından doğru ve etkili kullanmaları önerilmektedir (Campbell \& Martin, 2010; Coyle, Yanez \& Verdu, 2010; Mishra \& Koehler, 2006; Šumak vd., 2017). İlgili alanyazının taranması kapsamında öğretmen yetiştirme 
sürecinde ET kullanımına yönelik az miktarda çalışmaya erişim sağlanmıştır (Akyüz vd., 2014; Campbell \& Martin, 2010; Divaharan \& Koh, 2010; Hammond, Reynolds \& Ingram, 2011; Wong, Teo \& Goh, 2014, 2015). Bu çalışmaların çoğu belli bir alandaki ögretmen adaylarının ET ile ilgili deneyimleri ve görüşleriyle ilgilidir (Akyüz vd., 2014; Campbell \& Martin, 2010). Öğretmen yetiştiren fakültelerdeki öğretim elemanlarının ET ile ilgili deneyim ve düşünceleriyle ilgili herhangi bir çalışmaya rastlanmamıştır. Bu çalışmada hemen her alandaki öğretmen adayları ve onları öğretmenliğe hazırlamakla sorumlu olan öğretim elemanlarının deneyim ve görüşlerine yer verilmiştir. Bu bakımdan, bu çalışmanın alanyazına anlamlı bir katkı sağlaması beklenebilir.

$\mathrm{Bu}$ çalışmada öğretmen yetiştirme sürecinde eğitim fakültesi öğretim elemanlarının ve öğretmen adaylarının ET kullanma durumları ve ET kullanımına yönelik genel görüşleri belirlenmeye çalışılmıştır. Bu kapsamda aşağıdaki sorulara yanıt aranmıştır.

1. Eğitim fakültesi öğretim elemanları ve öğretmen adaylarının, genel bilgi ve iletişim teknolojileri ve ET kullanımına yönelik dağılımları nedir?

2. Eğitim fakültesi öğretim elemanları ET'lerin hangi özelliklerini kullanmaktadırlar?

3. Eğitim fakültesi öğretim elemanlarının ve öğretmen adaylarının ET kullanımına yönelik genel görüşleri nelerdir?

\section{Yöntem}

$\mathrm{Bu}$ çalışmada, devam etmekte olan bir durumla ilgili bazı betimlemelerin açıklanarak ortaya konması amacıyla betimsel tarama modeli kullanılmıştır (Büyüköztürk, Çakmak, Akgün, Karadeniz \& Demirel, 2017; Sönmez \& Alacapınar, 2011). Çalışmanın yapıldığı fakülteye ET kurulumu gerçekleştirildikten ve ilgili eğitim verildikten sonra 2015-2016 öğretim yılının her iki döneminde ET'ler öğretim elemanlarının ve öğretmen adaylarının kullanımına sunulmuştur. Böylece öğretim elemanlarının ve öğretmen adaylarının bir yıllık bir deneyim süreci geçirmeleri sağlanmıştır. Bir yıllık deneyim sürecinden sonra hem öğretim elemanlarından hem de ögretmen adaylarından bu deneyime yönelik veriler toplanmıştır.

\section{Örneklem}

Bu çalışmanın örneklemini 2015-2016 öğretim yılında Anadolu'da yer alan bir üniversitenin eğitim fakültesinde görev yapmakta olan öğretim elemanları ve bu fakülteye kayıtlı öğretmen adayları oluşturmaktadır. İlgili fakültedeki öğretim elemanları ve öğretmen adaylarının tamamından veri toplanması amaçlanmış ve 100'den fazla öğretim elemanı ve 2000'den fazla öğretmen adayına veri toplama araçları dağıtılabilmiştir. Ancak veri toplama süreci gönüllülük esaslı yürütüldüğü için 124 öğretim elemanının 35'inden (\%28) ve 3125 öğretmen adayının 969'undan (\%31) kullanılabilecek veri toplanabilmiştir. Bu iki guruba ait bazı betimsel istatistikler Tablo 1 ve Tablo 2'de sunulmuştur. 
Tablo 1

Öğretim Elemanlarının Bazı Betimsel İstatistikleri

\begin{tabular}{|c|c|c|c|c|c|c|c|c|c|c|c|c|c|c|}
\hline & & & \multicolumn{12}{|c|}{ Bölüm } \\
\hline & & & \multicolumn{2}{|c|}{ ВÖTE } & \multicolumn{2}{|c|}{ İngilizce } & \multicolumn{2}{|c|}{$\begin{array}{l}\text { Matematik } \\
\text { ve Fen }\end{array}$} & \multicolumn{2}{|c|}{$\begin{array}{l}\text { Sosyal } \\
\text { Bilimler ve } \\
\text { Türkçe }\end{array}$} & \multicolumn{2}{|c|}{ Temel Eğitim } & \multicolumn{2}{|c|}{ Toplam } \\
\hline & & & $N$ & $\%$ & $N$ & $\%$ & $N$ & $\%$ & $N$ & $\%$ & $N$ & $\%$ & $N$ & $\%$ \\
\hline \multirow{12}{*}{ Cins. } & \multirow{6}{*}{ Erk. Yaş } & $<31$ & 1 & 20.0 & 0 & 0.0 & 2 & 40.0 & 1 & 20.0 & 1 & 20.0 & 5 & 100.0 \\
\hline & & $31-35$ & 1 & 50.0 & 0 & 0.0 & 0 & 0.0 & 0 & 0.0 & 1 & 50.0 & 2 & 100.0 \\
\hline & & $36-40$ & 1 & 14.3 & 1 & 14.3 & 1 & 14.3 & 3 & 42.9 & 1 & 14.3 & 7 & 100.0 \\
\hline & & $41-45$ & 0 & 0.0 & 0 & 0.0 & 2 & 33.3 & 2 & 33.3 & 2 & 33.3 & 6 & 100.0 \\
\hline & & $>45$ & 0 & 0.0 & 1 & 14.3 & 6 & 85.7 & 0 & 0.0 & 0 & 0.0 & 7 & 100.0 \\
\hline & & Toplam & $n 3$ & 11.1 & 2 & 7.4 & 11 & 40.7 & 6 & 22.2 & 5 & 18.5 & 27 & 100.0 \\
\hline & \multirow{6}{*}{ Kdn. Yaş } & $<31$ & 0 & 0.0 & 0 & 0.0 & 0 & 0.0 & 0 & 0.0 & 0 & 0.0 & 0 & 0.0 \\
\hline & & $31-35$ & 0 & 0.0 & 1 & 25.0 & 0 & 0.0 & 2 & 50.0 & 1 & 25.0 & 4 & 100.0 \\
\hline & & $36-40$ & 1 & 50.0 & 0 & 0.0 & 1 & 50.0 & 0 & 0.0 & 0 & 0.0 & 2 & 100.0 \\
\hline & & $41-45$ & 0 & 0.0 & 0 & 0.0 & 0 & 0.0 & 0 & 0.0 & 1 & 100.0 & 1 & 100.0 \\
\hline & & $>45$ & 0 & 0.0 & 0 & 0.0 & 0 & 0.0 & 0 & 0.0 & 1 & 100.0 & 1 & 100.0 \\
\hline & & Toplam & & 12.5 & 1 & 12.5 & 1 & 12.5 & 2 & 25.0 & 3 & 37.5 & 8 & 100.0 \\
\hline Toplan & & & 4 & 11.4 & 3 & 8.6 & 12 & 34.4 & 8 & 22.8 & 8 & 22.8 & 35 & 100.0 \\
\hline
\end{tabular}

Kendilerinden veri toplanabilen öğretim elemanlarının 27'si (\%77) erkek ve 8'i (\%23) kadındır. Öğretim elemanları yaş dağılımlarına göre beş grup altında değerlendirilmişlerdir. Buna göre 31 yaşından küçük beş, 31-35 yaş aralığında altı, 3640 yaş aralığında dokuz, 41-45 yaş aralığında yedi ve 45 yaşından büyük sekiz öğretim elemanından veri toplanmıştır. Katılımcıların bölümlere göre dağılımları: BÖTE dört (\%11), İngilizce üç (\%9), Matematik ve Fen 12 (\%34), Sosyal Bilimler ve Türkçe sekiz (\%23) ve Temel Eğitim sekiz (\%23) şeklindedir. Güzel Sanatlar Eğitimi Bölümü öğretmen adaylarından veri toplanmış olmasına rağmen, bu bölümün öğretim elemanlarından veri toplanamamıştır.

Çalışmada 421'i (\%43) erkek, 548'i (\%57) kadın olmak üzere toplam 969 öğretmen adayından veri toplanmıştır. Katılımcıların yaşları 17 ile 38 arasında değişmekle beraber; frekans ve yüzde dağılımları göz önünde bulundurularak yaş dağılımları gruplandırılmıştır. Buna göre katılımcıların 182'si (\%19) 19 yaş, 196's1 (\%20) 20 yaş, 170'i (\%18) 21 yaş, 150'si (\%16) 22 yaş, 104'ü (\%11) 23 yaş ve 167'si (\%17) 24 yaş grubunda yer almıştır. Katılımcıların bölümlere göre dağılımları: BÖTE 82 (\%9), İngilizce 77 (\%8), Matematik ve Fen 341 (\%35), Sosyal Bilimler ve Türkçe 270 (\%28), Güzel Sanatlar 32 (\%3) ve Temel Eğitim 167 (\%17) şeklindedir. Katılımcıların 303'ü (\%31) birinci sinıfa, 273’ü (\%29) ikinci sinıfa, 153’ü (\%16) üçüncü sınıfa, 193’ü (\%20) dördüncü sınıfa ve 47'si (\%5) beşinci sınıfa kayıtlıydı. 
Tablo 2

Ögretmen Adaylarının Bazı Betimsel İstatistikleri

Bölüm

\begin{tabular}{lllll}
\hline \multirow{2}{*}{ BÖTE İngilizce } & Matematik Güzel & Sosyal & Temel \\
ve Fen & Sanatlar & Bilimler ve \\
Türkçe & Eğitim & Toplam
\end{tabular}

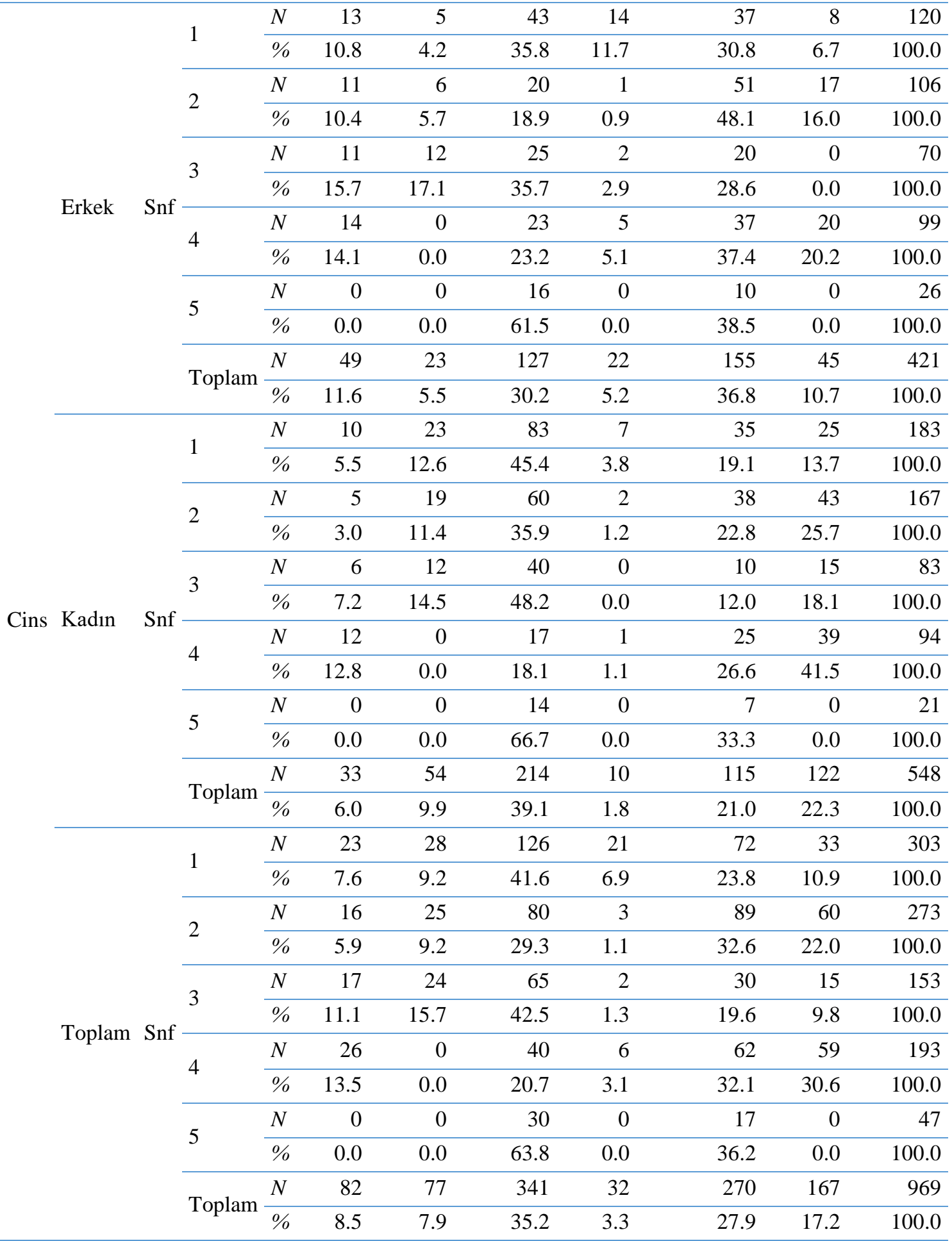

\section{Veri Toplama Araçları}

Araştırmada, biri öğretim elemanları diğeri ise öğretmen adayları için olmak üzere iki ayrı veri toplama aracı kullanılmıştır. Veri toplama araçlarında, öğretim elemanlarının ve öğretmen adaylarının bazı demografik özelliklerini, genel bilgi iletişim teknolojilerini ve ET kullanım durumlarını belirlemeye yönelik çoktan seçmeli sorulara 
yer verilmiştir. Bununla beraber hem öğretim elemanlarına hem de öğretmen adaylarına deneyimledikleri, eğitim sürecinde ET kullanımına yönelik genel görüş, beklenti ve önerilerinin sorulduğu açık uçlu sorular da veri toplama araçlarında yer almıştır. Hazırlanan veri toplama araçları, çalışmanın amacı açıklanarak biri ölçme değerlendirme, biri öğretim teknolojileri alanlarından olmak üzere iki uzmanın görüşüne sunulmuştur. Uzman görüşleri doğrultusunda araçların görsel geçerliğine katkı sağlayacağı önerilen bazı şekilsel değişikliklerle beraber açı uçlu soruların iyileştirilmesi için bazı ifade değişiklikleri yapılmıştır. Öğretim elemanları için hazırlanan veri toplama aracı iki öğretim elemanının, öğretmen adayları için hazırlanan veri toplama aracı ise yedi öğretmen adayının katılımıyla test edilmiştir. Teste katılan öğretim elemanları ve öğretmen adayları veri toplama araçlarının, anlaşırlığı, soruların sıralaması ve konumları, kullanılan yazı tipi ve boyutu ve formun uzunluğu ile ilgili herhangi bir sorun belirtmemişlerdir.

\section{Veri Analizi}

Çoktan seçmeli sorulara verilen yanıtlarla elde edilen nicel verilerin analizinde betimsel istatistikler kullanılmıştır. Öğretim elemanları ve öğretmen adaylarının ET kullanımına yönelik görüşlerini belirttikleri açık uçlu sorulara verilen yanıtlar ise nitel veri analiz yöntemlerinden olan içerik analizi ile değerlendirilmiştir. İçerik analizi ile gerçekleştirilen kodlamalar ve ulaşılan temalar başka bir araştırmacının incelemesine sunulmuş ve kendisinden teyit alınarak nitel analizin iç güvenirliğine katkı sağlanmıştır (Glesne, 2013; Patton, 2014; Yildirim \& Şimşek, 2005).

\section{Bulgular}

Bulgular araştırma sorularına göre sıralanarak sunulmuştur. Öğretim elemanları ve öğretmen adaylarının aynı soruya verdikleri yanıtların bulguları, daha etkili bir karşılaştırma sunabileceği değerlendirilerek aynı tabloda sunulmuştur (Örnek: Öğretim elemanlarına "Etkileşimli tahtayı derslerinizde kullanırken, tahtanın hangi özelliklerinden faydalanıyorsunuz?" sorusu sorulmuşken öğretmen adaylarına "Hocalarınız etkileşimli tahtayı derslerinizde kullanırken, tahtanın hangi özelliklerinden faydalanıyor?” sorusu sorulmuştur.).

\section{Eğitim Fakültesi Öğretim Elemanları ve Öğretmen Adaylarının ET Kullanımına Yönelik Dağılımları Nedir?}

Öğretim elemanları ve öğretmen adaylarının ET kullanımı dağılımları kapsamında ET kullanmayı bilme durumları, ET kullanımına yönelik eğitim alma istekleri ET kullanmayı nasıl öğrendikleri, ET kullanım deneyimleri (yıl bazında), kendilerini ne düzeyde bir ET kullanıcısı olarak tanımladıkları ve haftalık ET kullanım sıklıkları sorulmuştur. ET ile ilgili eğitim alma isteğinin ET kullanmayı bilme durumuyla ilgili olup olmadığı da ilgi çekici bulunarak bu durumun incelenmesi için bu iki değişkene ait bazı betimsel değerler Tablo 3 'te sunulmuştur. 
Tablo 3

Et Kullanmayı Bilme ve ET Ĕ̆itim İsteği



Öğretim elemanlarının 25'i (\%71) ET ile ilgili bir eğitime katılmak istediğini belirtmiştir. Bunların 21 (\%84) ET kullanmayı bildiğini belirten öğretim elemanlarıdır. Diğer taraftan ET ile ilgili bir eğitime katılmak istemediğini ve aynı zamanda ET kullanmayı bilmediğini bildiren öğretim elemanı sayısı 1'dir (\%10). Öğretmen adaylarından ET kullanmayı bildiğini belirttiği halde ET eğitimi almak isteyenlerin sayısı 297 (\%44) iken hem ET kullanmayı bilmediğini hem de ET ile ilgili bir eğitime katılmak istemediğini belirten öğretmen adayı sayısı 76'dır (\%26). Öğretim elemanları ve öğretmen adaylarının ET kullanmayı nasıl öğrendiklerine yönelik bulgular Tablo 4'te sunulmuştur.

Tablo 4

ET Kullanmayı Nasıl Öğrendiniz?

\begin{tabular}{lrrrr}
\hline & Öğretim elemanları & Öğretmen adayları & \\
\hline & $f$ & $\%$ & $f$ & $\%$ \\
Öğrenmedim & 5 & 14 & 452 & 47 \\
Kendi Kendime/Fakültedeki derslerde & 28 & 80 & 448 & 46 \\
Diğer & 2 & 6 & 69 & 7 \\
Toplam & 35 & 100 & 969 & 100 \\
\hline
\end{tabular}

Öğretim elemanlarının beşi (\%14) ET kullanmayı bilmediğini belirtirken bu sayı öğretmen adayları için 452'dir (\%47). ET kullanmayı kendi kendine/fakültedeki derslerde öğrendiğini belirten öğretim elemanlarının sayısı $28(\% 80)$ iken bu sayı öğretmen adayları için $448^{\prime}$ dir (\%46). Bu soruyu yanıtlarken diğer seçeneğini seçen öğretim elemanı sayısı iki (\%6) iken öğretmen adayı sayısı 69'dur (\%7). Öğretim elemanları diğer seçeneğine herhangi bir açıklama yazmazken öğretmen adaylarının büyük çoğunluğu (\%83) lisede/kursta/dershanede şeklinde yanıtlamışlardır. Öğretim elemanlarının ET kullanma süreleri Tablo 5'te sunulmuştur. 
Tablo 5

Öğretim Elemanlarının ET Kullanma Süreleri

\begin{tabular}{lll}
\hline & $f$ & $\%$ \\
\hline Kullanmiyorum & 7 & 20 \\
1 yildan az & 17 & 49 \\
$1-3$ yll & 11 & 31 \\
Toplam & 35 & 100
\end{tabular}

Öğretim elemanlarının yedisi (\%20) ET kullanmazken, 17’si (\%49) bir yıldan daha az bir süre ET kullanmıştır. ET kullanma süresini 1-3 yıl olarak işaretleyen öğretim elemanı sayısı 11 (\%31) iken üç yıldan daha uzun ET kullanım deneyimi olduğunu belirten öğretim elemanı olmamıştır. Öğretim elemanlarının kendilerini nasıl bir ET kullanıcısı olarak tanımladıklarına yönelik bulgular Tablo 6'te sunulmuştur.

Tablo 6

ET Kullanma Yeterlik Algiss

\begin{tabular}{lll}
\hline & $f$ & $\%$ \\
\hline Yetersiz & 3 & 9 \\
Acemi & 6 & 17 \\
Orta & 20 & 57 \\
İyi & 4 & 11 \\
Uzman & 2 & 6 \\
Toplam & 35 & 100 \\
\hline
\end{tabular}

ET kullanma yeterliği bakımından öğretim elemanlarının üçü (\%9) kendilerini yetersiz, altısı (\%17) acemi, 20'si (\%57) orta, dördü (\%11) iyi ve ikisi (\%6) uzman düzeyde görmektedirler. Öğretim elemanlarının bir haftada ET kullanma sıklıkları ile ilgili hem öğretim elemanları hem de öğretmen adaylarının yanıtları ve öğretmen adaylarının kendi haftalık ET kullanımına yönelik verileri Tablo 7'da sunulmuştur.

Tablo 7

Haftalık ET Kullanma Siklı̆̆

\begin{tabular}{lllllll}
\hline & & \multicolumn{2}{l}{$\begin{array}{l}\text { Öğğretmen adaylarına göre } \\
\text { göre kendi kullanımları }\end{array}$} & $\begin{array}{l}\text { öğretim elemanlarının } \\
\text { kullanımı }\end{array}$ & $\begin{array}{l}\text { Ögretmen adaylarına göre } \\
\text { kendi kullanımları }\end{array}$ \\
& $f$ & $\%$ & $f$ & $\%$ & $f$ & $\%$ \\
Hiç & 7 & 20 & 238 & 24 & 356 & 36 \\
$1-5$ saat & 10 & 29 & 583 & 60 & 298 & 31 \\
6-10 saat & 4 & 11 & 123 & 13 & 112 & 13 \\
$11-15$ saat & 9 & 26 & 18 & 2 & 193 & 19 \\
16 saat ve üzeri & 5 & 14 & 7 & 1 & 10 & 1 \\
Toplam & 35 & 100 & 969 & 100 & 969 & 100
\end{tabular}

Öğretim elemanlarından yedisi (\%20) kendilerinin, öğretmen adaylarından 238'i (\%24) derslerine giren öğretim elemanlarının hiç ET kullanmadığını belirtirmiştir. Hiç ET kullanmadığını belirten öğretmen adayı sayısı ise 356'dır (\%36). Haftalık 1-5 saat 
ET kullanımı için bu sayı ve oranlar sırasıyla 10 (\%29), 583 (\%60) ve 298'dir (\%31). Haftalık 6-10 saat ET kullanımı için bu sayı ve oranlar sırasıyla 4 (\%11), 123 (\%13) ve 112'dir (\%13). Haftalık 11-15 saat ET kullanımı için bu sayı ve oranlar sırasıyla 9 (\%26), 18 (\%2) ve 193'dir (\%19). Haftalık 16 saat ve üzeri ET kullanımı için bu sayı ve oranlar sirasiyla $5(\% 14), 7$ (\%1) ve 10 'dir (\%1).

\section{Eğitim Fakültesi Öğretim Elemanları ET'lerin Hangi Özelliklerini Kullanmaktadırlar?}

Öğretim elemanlarının derslerinde ET'lerin hangi özelliklerinden yararlandıklarının belirlenmesi amacıyla hem öğretim elemanlarına hem de öğretmen adaylarına, en çok kullanılan ET özelliklerinin seçenekler halinde sunulduğu bir soru sorulmuştur. Soru yanıtlanırken birden fazla seçeneğin seçilebileceği belirtilmiştir. Bununla beraber listelenen özelliklerden farklı özelliklerin de belirtilebilmesi için "diğer" başlığı altında açık uçlu bir alanda bırakılmıştır. Öğretim elemanlarının ve öğretmen adaylarının bu soruya verdikleri yanıtlar Tablo 8'de sunulmuştur.

Tablo 8

Öğretim Elemanlarının En Çok Kullandıkları ET Özellikleri ${ }^{*}$

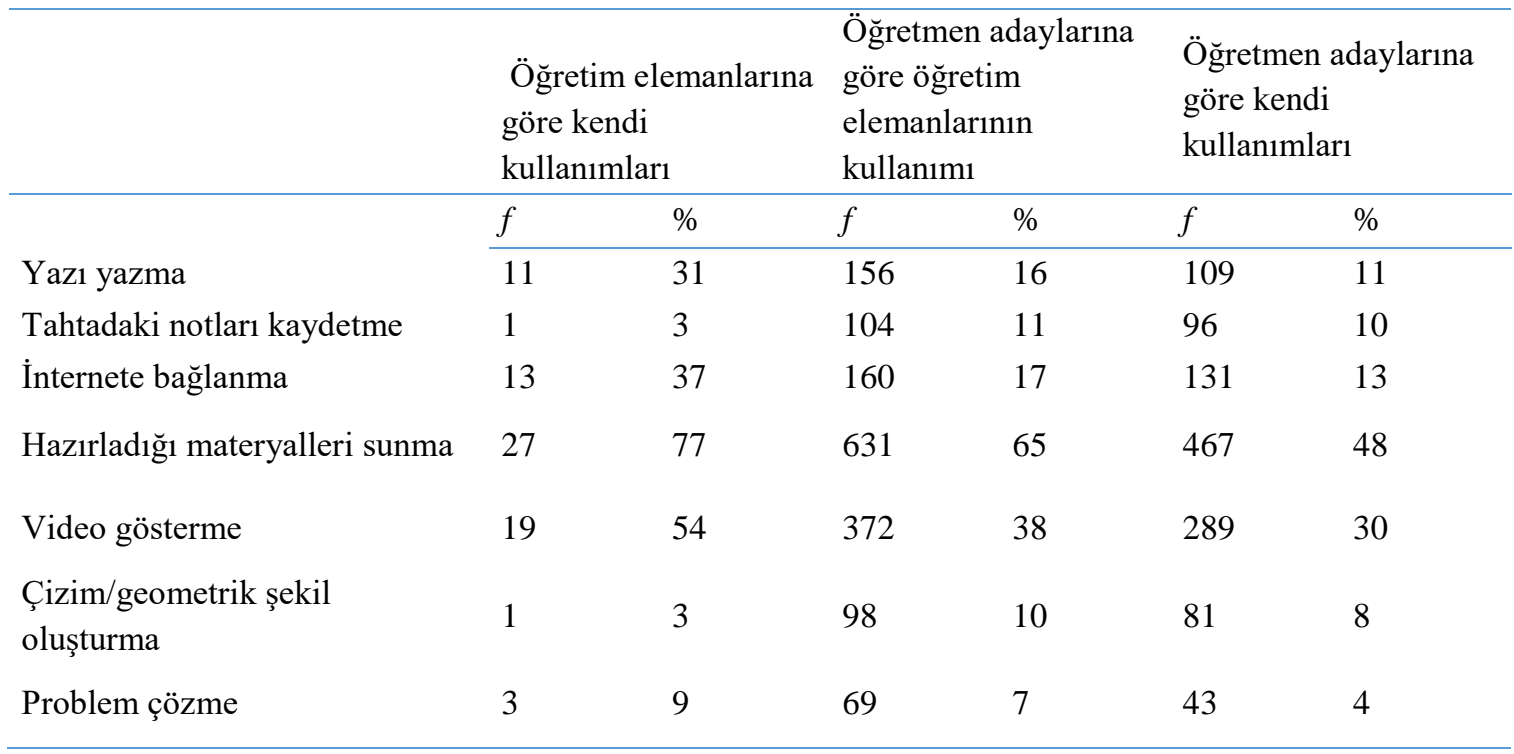

*Birden fazla seçenek belirtilebildiği için tabloda toplam satırına yer verilmemiştir.

Hem öğretim elemanlarına hem de öğretmen adaylarına göre öğretim elemanlarının en çok kullandığı ET özellikleri "Hazırladığ 1 materyali sunma" (\%77 ve \%65), "Video gösterme" (\%54 ve \%38) ve "İnternete bağlanma" (\%37 ve \%13) olmuştur. Bu özellikler için öğretmen adaylarının kendi kullanımları ise sırasıyla \%48, \%30 ve \%13'tür. ET'lerin "Yazı yazma" (\%31 ve \%11), “İnternete bağlanma” (\%37 ve \%13) ve "Video gösterme" (\%54 ve \%38) özelliklerinin kullanılması bakımından öğretim elemanlarının belirttiği oranlar öğretmen adaylarının belirttiği oranlardan daha yüksektir. Diğer taraftan "Tahtadaki notları kaydetme" (\%3 ve \%11) ve "Çizim/geometrik şekil oluşturma" (\%3 ve \%10) özelliklerinin kullanılması yönünden öğretmen adaylarının belirttiği oranlar öğretim elemanlarının belirttiklerinden daha yüksektir. 


\section{Ĕ̆itim Fakültesi Öğretim Elemanları Ve Öğretmen Adaylarının ET Kullanımına Yönelik Genel Görüşleri Nelerdir?}

Öğretim elemanları ve öğretmen adaylarına ET kullanımına yönelik genel görüş, beklenti ve önerilerinin sorulduğu açık uçlu sorular sorulmuştur. Katılımcılardan ET ile ilgili görüşlerini bildiren öğretim elemanı sayısı 32 (\%91) iken öğretmen adayı sayısı 284 (\%29) olmuştur. Öğretim elemanları ve öğretmen adaylarının yanıtları nitel analiz yöntemlerinden içerik analiz yöntemi kullanılarak çözümlenmiştir. Tablo 9'da bu yanıtların analiziyle elde edilen temalar ve bu temalara ait kodlanma sayılarına yönelik basit betimsel istatistikler sunulmuştur.

Tablo 9

İçerik Analiziyle Elde Edilen Temalar

\begin{tabular}{|c|c|c|c|c|c|}
\hline \multirow{2}{*}{ Tema } & \multirow{2}{*}{ Açıklama } & \multicolumn{2}{|c|}{ Öğretim elemanları } & \multicolumn{2}{|c|}{ Öğretmen adayları } \\
\hline & & $N$ & $\%$ & $N$ & $\%$ \\
\hline ET kullanma yetisi & $\begin{array}{l}\text { ET ve ET özelliklerini yeterli ve etkili } \\
\text { kullanabilme }\end{array}$ & 6 & 15 & 115 & 27 \\
\hline ET sorunları & $\begin{array}{l}\text { ET kullanımı sürecinde deneyimlenen } \\
\text { teknik ve pedagojik sorunlar }\end{array}$ & 13 & 31 & 68 & 16 \\
\hline ET potansiyeli & ET kullanımının sağlayabilecekleri & 8 & 20 & 73 & 17 \\
\hline $\begin{array}{l}\text { ET } \\
\text { memnuniyet/tercih }\end{array}$ & $\begin{array}{l}\text { ET kullanılmasını isteme veya } \\
\text { istememe }\end{array}$ & 9 & 22 & 92 & 21 \\
\hline Diğer & $\begin{array}{l}\text { Doğrudan ET kullanmaktan } \\
\text { kaynaklanmayan durumlar }\end{array}$ & 5 & 12 & 81 & 19 \\
\hline Toplam & & 41 & 100 & 429 & 100 \\
\hline
\end{tabular}

Öğretim elemanı ve öğretmen adaylarının görüşleri "ET kullanma yetisi”, "ET sorunları", "ET potansiyeli", "ET memnuniyet/tercih" ve "Diğer" temaları altında kodlanmıştır. Öğretim elemanlarının ifadelerinden, bu temalardan en çok "ET sorunları" teması (\%31), en az ise "Diğer" teması altında kodlama yer almıştır. Öğretmen adayları için ise en çok "ET kullanma yetisi" (\%27) ve en az "ET sorunları" temalarında kodlamalar yer almıştır.

"ET kullanma yetisi” teması altında öğretim elemanları ve öğretmen adaylarının ET kullanmayı bilmeme veya yeterli düzeyde bilmeme ve ET kullanımına yönelik eğitim talebi görüşlerine yer verilmiştir. Bu görüşlerden bazıları şöyledir.

“Aslında çok daha fazla özelliği olmasına ră̆men yeterli hissetmediğimden hakkını vermediğimi düşünüyorum.” Öğretim Elemanı 7

“Gerekli eğitimin verilmeyişi olumsuz etkiliyor" Öğretim Elemanı 1

"Daha etkin bir kurs veya uzmanlı alanı olan birinden seminer şeklinde bir eğitim verilseydi" Öğretim Elemanı 23

"Yeterince bilgilendirme yapılmalı ve materyal dersinde ögrrencilere ögrretilmeli." Öğretmen Adayı 135

“Anlamıyorum, bilmek istiyorum, kullanmak isterim.” Öğretmen Adayı 234

“Keşke kullanımını bize de ögretseler.” Öğretmen Adayı 587

Hem öğretim elemanlarının hem de öğretmen adaylarının görüşlerinden ET kullanımına yönelik kendilerini yeterli hissetmedikleri anlaşılabilir. Öğretim elemanları ET'leri derslerinde kullanıyor olsalar da ET'lerin daha fazla ve farklı özelliklerinin olduğunun farkındalar ancak bu özelliklerin neler olduklarını ve bu özellikleri nasıl 
kullanacaklarını bilmiyor olabilirler. Bu nedenle ET'ler ile ilgili daha kapsamlı bir eğitim talebini dile getirmiş olabilirler. Diğer taraftan öğretmen adaylarının görüşlerinden, öğretmen adaylarının ET kullanımı konusunda daha yetersiz oldukları anlaş1labilir. Hatta öğretmen adayı 234 ve 87'nin ifadelerinde ET kullanımına dair herhangi bir deneyim ve bilgilerinin olmadığı sonucu da çıkarılabilir.

"ET sorunları" teması altında öğretim elemanları ve öğretmen adaylarının, öğretim sürecinde ET kullanımından kaynaklandığını düşündükleri, doğrudan ET kullanımı ile ilgili veya dolaylı olarak, ET kullanımının uzanımı olarak gördükleri sorunlara yer verilmiştir. Belirtilen sorunlardan bazıları şöyledir.

"Daha çok lise sinıflarına göre yani küçük. daha büyük sinıflarda görüntü ve ses yetersiz." Öğretim Eleman 12

"Yazılımı sürekli hata veriyor.” Öğretim Elemanı 17

“Arka sırada oturan ögrrencilerin görüşünü azalttığını düşünüyorum.” Öğretim Eleman 5

“Öğrenci-öğretmen ilişkisini zedeliyor.” Öğretmen Aday1 549

"Ders amaçlı kullanmadıkları için sakıncalı görüyorum." Öğretmen Adayı 345

"Bence çok gereksiz. Öğrencinin derse tam olarak odaklanmasinı engelliyor. Hoca da sadece tahtada gördüklerini okuyor." Öğretmen Adayı 859

Öğretim elemanları daha çok ET’lerin yazılımsal ve donanımsal sorunları ve yetersizlikleri ile ilgili ifadeler kullanmışlardır. Buna karşın öğretmen adayları daha çok ET kullanımının öğrenme ortamına ve sürecine olumsuz etkilerini dile getirmişlerdir.

"ET potansiyeli” teması altında öğretim elemanları ve öğretmen adaylarının bir yıllık deneyimlerinde görememiş olsalar da, etkili ve doğru bir ET kullanımına yönelik görüşlerine yer verilmiştir. Bu görüşlerden bazıları şöyledir.

"Kullanımınin olumlu sonuçlar doğuracăğna inanıyorum" Öğretim Elemanı 3

"Verimli kullanılırsa harika bir araç." Öğretim Elemanı 32

“Amaca yönelik abartılmadan kullanıldı̆ğıda iyi olur, faydalıdır.” Öğretmen Aday1 29

"Amacı ve kullanımına uygun kullanıldı̆ğ taktirde kalıcı ögrenmeyi să̆lar." Öğretmen Aday1 635

“Belirli derslerde görsel zekanın ortaya çıkması için kullanılmalıdır.” Öğretmen Adayı 952

Öğretim elemanları ET kullanımının özellikle verimli kullanılması doğrultusunda, olumlu sonuçlar doğuracağını belirtmişlerdir. Öğretmen adayları ise belirli bir amaç doğrultusunda uygun ders ve konularda uygun kullanımı ile yarar elde edilebileceğini belirtmişlerdir.

"ET memnuniyet/tercih" teması altında öğretim elemanları ve öğretmen adaylarının ET kullanımı ile ilgili memnuniyetleri ve ET kullanımını tercih edip etmeme ile ilgili görüşleri yer almıştır. Bu görüşlerin bazıları şöyledir.

“Gayet işlevsel.” Öğretim Elemanı 17

"Kullanılırsa faydalı da olabilir. Ancak ben tercih etmiyorum." Öğretim Elemanı 8

"Hoca slayt açar, öğretmen okur ve ögrenci dinler. Uykum geliyor derste. Slaytı ordan izlemektense gidip evde internetten okurum." Öğretmen Aday1 471

"Allah aşkina çok slkıcı bence." Öğretmen Adayı 726

"Bence daha çok kullanılmalıdır." Öğretmen Adayı 693

ET kullanımına yönelik görüş belirten katılımcıların çoğu (öğretim elemanlarının \%78'i, ve öğretmen adaylarının \%65'i) olumlu görüş bildirerek ET kullanımını tercih ettiklerini ifade etmişlerdir. Öğretim elemanlarının görüşlerinden ET'leri oldukça işlevsel buldukları, kullanımın yararlı olabileceğini düşündükleri ancak 
buna rağmen kullanmayı tercih etmeyebilecekleri söylenebilir. Öğretmen adayları ise daha çok ET kullanımının yansıtım cihazı işlevi ile sınırlandırılmasından ve öğretim elemanlarının öğretim sürecinde daha pasif olmasından memnuniyetsizliklerini ifade etmişlerdir. Bununla beraber ET'lerin kullanımının arttırılması gerektiğini ifade ederek memnuniyetini belirten öğretmen adayları da olmuştur.

"Diğer" teması altında öğretim elemanları ve öğretmen adaylarının, doğrudan ET kullanımı ile ilgili deneyimlerinden kaynaklanmayan ancak ET kullanımı etkileyebileceği düşünülen görüşlerine yer verilmiştir. Bu görüşlerden bazıları şöyledir.

"Datashow olursa daha iyi olur." Öğretim Elemanı 8

"Derslerim için projektör vazifesi görüyor." Öğretim Elemanı 18

"Bence hocalarımız dersten sogutuyor sadece slayt ortaminda ders işlenilmesi etkili olmuyor." Öğretmen Adayı 714

"Biz kullanmiyoruz genelde kilitli oluyor." Öğretmen Adayı 423

Öğretim elemanlarının bazıları ET'leri yansıtım cihazı ile ilişkilendirmiş ve ET'lerdense yansıtım cihazlarını kullanmayı tercih ettiklerini veya ET'leri sadece yansıtım cihazı gibi kullandıklarını belirtmişlerdir. Öğretmen adayları ise öğretim elemanlarının ET kullanımından memnun olmadıklarına yönelik izlenimlerini belirtmişlerdir. Bununla beraber sınıflarında ET olmasına rağmen, ET'lerin kullanılmadığını belirten öğretmen adayları $(n=69)$ da bulunmaktadır.

\section{Tartışma ve Sonuç}

$\mathrm{Bu}$ çalışmada öğretmen yetiştirme sürecinde ET kullanımına yönelik öğretim elemanlarının ve öğretmen adaylarının görüşleri belirlenmeye çalışılmıştır. Öğretim elemanlarının ve öğretmen adaylarının bir yıllık ET kullanma deneyimleri sonrasında kendilerinden elde edilen verilerin çözümlenmesi sonucunda öğretim elemanlarının ve öğretmen adaylarının ET ile ilgili görüşlerinin genel olarak olumlu olduğu söylenebilir. Alanyazında bu durumu destekleyen birçok çalışma bulunmaktadır (Badilla Quintana, 2012; Bakadam \& Asiri, 2012; Bidaki \& Mobasheri, 2013; Divaharan \& Koh, 2010; Emeagwali \& Naghdipour, 2013; Gadbois \& Haverstock, 2012; Gregory, 2010; Ipek \& Sözcü, 2016). Bu çalışmaların çoğunda ET ile ilgili öğrenci ve öğretmenlerin görüş ve düşüncelerine yer verilmiş; ET kullanma oranı ve niteliğine bağlı olarak bu görüş ve düşüncelerin artış gösterdiği belirtilmiştir. Alanyazındaki bu ifadeler ile bu çalışmadaki öğretim elemanlarının ve öğretmen adaylarının ET kullanma miktarı ve nitelikleri göz önünde bulundurulunca, bu çalışmadaki durum daha çok bir yenilik etkisi şeklinde değerlendirilebilir.

ET ile ilgili bir eğitim almak istediklerini belirten öğretim elemanları ile böyle bir eğitim almak istemeyen öğretim elemanlarının görüşleri arasında anlamlı bir farklılık gözlenmemesine karşın, ET ile ilgili eğitim almak isteyen öğretmen adaylarının istemeyen öğretmen adaylarına göre daha olumlu görüşlere sahip oldukları görülmüştür. Bununla beraber ET kullanmayı bildiğini belirten öğretim elemanlarının büyük çoğunluğu (\%84) ET ile ilgili eğitim almak isterken bu oran öğretmen adayları için daha düşüktür (\%44). Diğer taraftan hem ET kullanmayı bilmediğini belirten hem de ET ile ilgili eğitim almak istemeyen öğretim elemanı oranı oldukça düşükken (\%10), bu oran öğretmen adayları için daha yüksektir (\%26). Var olan durumda öğretmen olarak çalışan hemen herkes ET kullanmak zorundayken, öğretmen adaylarının hem ET kullanmayı 
bilmemeleri hem de bu konuyla ilgili eğitim almak istememeleri hem düşündürücü hem de üzerinde çalışılması gereken önemli bir durum olarak düşünülebilir.

ET ile ilgili genel görüş, düşünce ve önerilerin sorulduğu açık uçlu sorulara verilen yanıtlara göre, hem öğretim elemanları hem öğretmen adayları ET kullanma yetisine vurgu yapmış ve kendilerini ET kullanımı bakımından yeterli görmemiş ve bu konuda eğitim almak istediklerini vurgulamışlardır. ET kullanma yetisi, öğretmen adaylarının en çok değindiği konu iken öğretim elemanları için en az değinilen konu olmuştur. Öğretim elemanları en çok ET kullanımına yönelik yaşadıkları sorunları dile getirirken, bu konu öğretmen adaylarının en az değindiği konu olmuştur. Diğer taraftan öğretim elemanları ET'lerle ilgili yaşadıkları yazılımsal ve donanımsal sorunları dile getirirken, öğretmen adayları daha çok öğrenme sürecindeki pedagojik unsurlara dikkat çekmişlerdir. Öğretim elemanlarının ve öğretmen adaylarının bu görüş ve düşüncelerinin daha sağlıklı değerlendirilmesi adına araştırmacıların bu sürece yönelik gözlem ve saptamalarına yer verilmesi uygun görülmüştür. İlgili fakültede BÖTE bölümü dışındaki bölümlere ET'ler kurulmadan önce BÖTE bölümünde ET bulunmaktaydı. BÖTE bölümü diğer bölümlerdeki öğretmen adaylarına yönelik bir eğitim takvimi oluşturarak bu bölümlere duyurmuş ve öğrencilerini bu eğitime getirmeleri için davet göndermiştir. Buna rağmen bu davete uyan yalnızca iki sınıf (iki şube) olmuştur. ET'ler diğer bölümlere kurulduktan sonra ET'ler ile ilgili eğitim yapılacağının duyurulmasına rağmen ilgili eğitime katılan öğretim elemanı sayısı 14 olmuştur. ET'lere Microsoft Windows 7 işletim sistemi, ofis paket yazılımı, internet tarayıcılar, dokuman okuyucular ve medya oynatıcılar gibi herhangi bir kişisel bilgisayarda kullanılan genel amaçlı yazılımlar kurulmuştur. Kurulan ET'lerin devamlılığının sağlanabilmesi için ET'ler her başlatıldığında, ET üzerinde kurulu olan sistemi eski haline getiren bir yazılım yüklenmiştir. Bu yazılım ET sistemlerinin beklenenden daha yavaş çalışmasına yol açabilmektedir. Aynı yazılım aynı zamanda ET'ler üzerine yeni yazılımların kalıcı olarak kurulmasına da izin vermemektedir. Bu nedenle öğretim elemanlarına alanlarına veya derslerine yönelik kullanmak istedikleri yazılımların kurulması için talepte bulunmaları halinde ilgili yazılımların ET sistemlerine kalıcı olarak kurulabileceği duyurulmuştur. Bir yıllık süre zarfında bu amaçla iletilen talep sayısı ikidir. Ayrıca kişisel bilgisayarlarını ET'lere bağlayarak kullanmak isteyen öğretim elemanları bunu nasıl gerçekleştirebileceklerini sormuşlardır. Bununla beraber araştırmacıların gözlemleri, öğretmen adaylarının ve hatta öğretim elemanlarının kendi ifadeleri, ET'lerin neredeyse tamamen bilgisayar ve yansitma cihazı ile sunum yapar gibi kullanıldığına işaret etmektedir. Buna benzer durumlar alanyazın (Bakadam \& Asiri, 2012; Bruffaerts-Thomas \& Bruffaerts, 2013; Hammond vd., 2011; Jang, 2010; Jang \& Tsai, 2012b) tarafindan da desteklenmektedir. Bu çalışmalardan sadece Hammond vd. (2011) tarafından gerçekleştirilen çalışma, öğrencilerin ET kullanma oranlarının yüksek olması nedeniyle farklı değerlendirilebilir. $\mathrm{Bu}$ çalışmanın bulguları öğretmen adaylarının ET kullanma oranlarının oldukça düşük olduğuna işaret etmektedir.

Anılan sonuç ve görüşlere katkı sağlayabileceği düşüncesiyle devam etmekte olan başka bir çalışmada dikkat çeken bir noktanın paylaşılması yararlı görülmüştür. Şöyle ki; bir yıllık deneyim sonunda, bu çalışmanın ilk bulguları ve öğretim elemanlarıyla görüşmeler yapılarak; bu görüşmeler doğrultusunda daha çok alanlara yönelik yazılımların kullanımını da içeren bir eğitim tasarlanmıştır. Bu eğitim ile ilgili 
ögretim elemanlarına e-posta yoluyla duyuru yapılmış, basılı davetiyeler hazırlanmış ve hazırlanan davetiyelerin bütün öğretim elemanlarının odalarına bırakılması sağlanmış olmasına rağmen, bu eğitime katılım dört öğretim elemanı ile sınırlı kalmıştır.

$\mathrm{Bu}$ çalışmanın bulguları halen devam etmekte olan, eğitimde teknoloji kullanımıyla ilgili, dünyadaki en büyük projelerden biri olan FATİH projesinin etkin aktörlerinin yani öğretmen adaylarının gerekli niteliklerde yetiştirilmesine katkıda bulunabilir (Aslında bu niteliklerin günümüzde bir öğretmenden beklenen nitelikler olduğu da ilgili ve anılan alanyazın tarafından da desteklenmektedir). Bu katkının sağlanabilmesi için çalışmanın ortaya çıkardığı sonuçların ve bu sonuçlar doğrultusunda sunulan önerilerin sıralanması uygun görülmüştür.

$>$ Öğretim elemanları ve öğretmen adayları öğretim elemanlarını ET kullanımı bakımından yeterli görmemektedirler. Bu nedenle eğitim fakültesi öğretim elemanlarına bu yönde bir eğitim verilmesi önerilmektedir. Ancak bu tür eğitimlere katılımın gönüllülük esasına bağlı olması istenen sonucu vermemektedir. Dolayısıyla öğretim elemanlarının bu eğitimlere katılımının sağlanması yönünde idari yaptırımların uygulanması önerilmektedir.

$>\mathrm{Bu}$ eğitimlerin alan öğretim elemanlarına özel, kendi alanlarıyla ilgili, özellikle ET ile daha etkili kullanılabilecek yazılımları da kapsar nitelikte olması bu eğitimlerin daha anlamlı ve etkili olmasını sağlayabilir.

$>$ Öğretmen adayları ET kullanımı konusunda kendilerini yeterli görmemektedirler. Öğretmen adaylarının eğitim fakültelerindeki eğitim süreçlerinde ET ile ilgili bir düzenleme yapılması yararlı olabilir. Bu bağlamda her anabilim dalında, her öğretmen adayının ET kullanmasını gerektirecek bir seçmeli ders eklenmesi veya var olan, kapsamı bu duruma uygun derslerden birinin içeriğinin buna uygun düzenlenmesi sağlanabilir.

$>$ ET ile ilgili daha düşük yaş/sınıf gruplarında algının daha az olumlu olduğu dikkate alınarak bu tür düzenlemeler birinci sınıflara yansıtılacak şekilde gerçekleştirilebilir.

$>$ İngilizce, Sosyal Bilimler ve Türkçe gibi bazı bölümlerdeki öğretmen adaylarının ET'ye yönelik algıları daha az olumludur. $\mathrm{Bu}$ alanlara özel yazılımların öğretim sürecinde etkin kullanımı bu bölümlerdeki öğretmen adaylarının olumlu görüşlerine katkıda bulunabilir.

$>$ ET'ler ile ilgili yaşanan yazılımsal ve donanımsal sorunlar özellikle öğretim elemanları tarafından dile getirilmiştir. Bu tür sistemlerin özellikle uzun süreli sorunsuz kullanılabilmesi oldukça zordur. Bu tür sorunların özellikle kullanıcı özellikleri dikkate alınınca sıklıkla yaşanabileceği beklenebilir. Bu nedenle ET kullanılacak birimlerde (fakülte, okul vb.) ET bakım ve onarımından sorumlu birey ve birimlerin görevlendirilmesi yararlı olacaktır (Al-Qirim, 2011; Bruffaerts-Thomas \& Bruffaerts, 2013).

$>$ Bazı öğretim elemanları ve bazı öğretmen adayları ET'lerin sınıflar için küçük sayılabilecek ekranları olduğunu ve ses açısından da yeterli olmadığını belirtmişlerdir. Bu duruma yönelik sınıf mevcutlarının düşürülmesi (Bakadam \& Asiri, 2012) veya daha büyük ve donanımsal olarak daha üstün ET'lerin kullanılması önerilebilir.

$>$ Özelde, ilgili eğitim fakültesinde, genelde FATİH projesi kapsamında yapılan bu tür yatırımların boşa gitmemesinin, bu yatırımların amaçları doğrultusunda etkili 
ve doğru kullanılmalarına bağlı olduğu söylenebilir. $\mathrm{Bu}$ nedenle bu tür yatırımların bu çalışma gibi çalışmalarla değerlendirilmesi yararlı olabilir. Gelecekteki çalışmaların daha anlamlı ve etkili olması adına, bu tür değerlendirmeler yapılırken MEB bünyesinde hizmete devam etmekte olan, özellikle hizmette ilk yıllarını yaşayan öğretmenlerin görüş, öneri ve beklentileri de -özellikle MEB bünyesindeki ilgili birimlerin ET'lere özel yazılımlar geliştirdikleri de göz önünde bulundurularak- dikkate alınabilir. 


\section{Summary}

Purpose and significance: Teacher trainers (academicians) are advised to use these technologies correctly and effectively in the process of teaching and training (Campbell \& Martin, 2010, Coyle, Yanez \& Verdu, 2010, Mishra \& Koehler, 2006; Šumak, Pušnik, Heričko and Šorgo, 2017). Number of studies that related to interactive whiteboard (IWB) use in the course of teacher training is limited (Akyüz vd., 2014; Campbell \& Martin, 2010; Divaharan \& Koh, 2010; Hammond, Reynolds \& Ingram, 2011; Wong, Teo \& Goh, 2014, 2015). Most of these studies relate to the experience and opinions of teacher trainees in a particular area (Akyüz et al., 2014; Campbell \& Martin, 2010). There were no studies related to the IWB experience and thoughts of the teacher trainers. In this study, the experiences and opinions of the teacher trainers and teacher trainees in almost every area were examined. From this point of view, this study can be expected to make a meaningful contribution to the literature.

Method: In this study, a descriptive survey model was used. The IWBs were offered for the use of teaching trainers and teacher trainees during the two semesters of the 20152016 academic year. After the establishment of IWBs in the faculty, a basic training on how to use them was offered. Thus, teaching trainers and teacher trainees are provided with a one-year experience. After one year of experience, data was collected from them. Participants of this study are teacher trainers and teacher trainees of an education faculty in the 2015-2016 academic year. Data could be collected from 35 of 124 instructors (28\%) and 969 of 3125 teacher candidates (31\%). Data collection tools include multiple-choice questions to determine some demographic and IWB use characteristics of the participants. Open-ended questions about the general views, expectations and suggestions for the use of IWB in the educational process were also included in the data collection tools. Descriptive statistics were used in the analysis of quantitative data. The answers given to the open-ended questions were evaluated by content analysis. The content analysis and presentation of the themes were presented to another researcher's review and confirmed by themselves, contributing to the internal reliability of the qualitative analysis (Glesne, 2013, Yildirim \& Şimşek, 2005).

Results: Twenty-five of the teacher trainers $(71 \%)$ stated that they wanted to participate in an IWB related training. Twenty-one instructors (84\%) said they knew to use IWB. On the other hand, the number of teacher trainers who reported that they did not want to participate in IWB related training and that they did not know how to use IWB at the same time was $1(10 \%)$. Teacher trainees who indicated that they knew to use IWB, and also wanted to take IWB training was $297(44 \%)$. Five of the teacher trainers $(14 \%)$ stated that they did not know how to use IWB, whereas this number was 452 (47\%) for teacher trainees. The number of teacher trainers who stated that they learned to use IWB in their own /during faculty courses is $28(80 \%)$ whereas this number is $448(46 \%)$ for teacher trainees. Seven of the trainers (20\%) did not use IWB, while 17 (49\%) used IWB for less than one year. The number of trainers who marked the IWB use period as 1 to 3 years was $11(31 \%)$, but no one indicated that the IWB experience was longer than three years. Three (9\%) of the trainers see themselves as inadequate, six (17\%) are novice, $20(57 \%)$ are moderate, four $(11 \%)$ are good and two $(6 \%)$ are experts in using 
IWB. Three hundred and fifty-six trainees (36\%) stated that they did not use IWB at all. According to both the trainers and trainees, the IWB features most frequently used by the trainers were "presenting the prepared material" (77\% and 65\%), "video showing" (54\% and 38\%) and "internet use" (37\% and 13\%). The trainees' own use for these traits is $48 \%, 30 \%$ and $13 \%$, respectively. The views of the trainers and trainees are coded under "ability to use IWB", "IWB problems", "IWB potential", "IWB satisfaction I preference" and "Other". Among the expressions of the trainers, the most frequently mentioned "IWB problems" (31\%), at least under "Other" coded. For the trainees, the most "ability to use IWB" (27\%) and at least "IWB problems" included coding in the themes. It can be understood that both the trainers and the trainees do not feel adequate enough to use IWB. The trainers mostly mentioned software and hardware problems and deficiencies of the IWBs. The trainees, on the other hand, stated that the use of IWB was adversely affecting the learning environment and the process. Most participants ( $78 \%$ of the trainers, and $65 \%$ of trainees) expressed a positive opinion and stated that they preferred using IWB. The views of the trainers suggest that IWBs are highly functional, they may think that use may be beneficial but nevertheless they prefer not to use it. The trainees are more dissatisfied because IWB use is limited by the function of projection devices and the trainers are more passive in the teaching process.

Discussion and Conclusion: Findings of this study can contribute to the training of the prospective teachers. In order to achieve this contribution, the following suggestions can be made in the light of the results of the study. Education faculty instructors are to provide training for the use of IWB. However, participation in such trainings is voluntary. It is therefore recommended that administrative sanctions be imposed in order to ensure the participation of instructors in these trainings. Including field specific educational software trainings can make these trainings more meaningful and effective. Teacher candidates do not see themselves adequate enough to use IWB. It may be useful to make an IWB-related arrangement in the training processes. In this context, it is possible to provide an elective course that requires each teacher candidate to use IWB, or to arrange the content of one of the appropriate courses in the context of this subject. Considering that the IWB is less favorable for the lower age / class groups, such arrangements can be implemented as reflected in the first grade. Teacher candidates in some departments such as English, Social Sciences and Turkish have less perceptions towards IWB. The effective use of special software in these areas can contribute to the positive opinions of the teacher candidates in these areas. The software and hardware problems experienced with IWBs have been especially expressed by the trainers. It is quite difficult to use such systems especially for a long time without problems. It can be expected that such problems can be experienced frequently, especially considering user characteristics. For this reason, it will be useful to appoint individuals and units responsible for IWB maintenance and repair in the units (faculty, school, etc.) using IWB. Some trainers and some trainees have stated that IWBs have small screens for classes and are not enough in terms of sound. It may be advisable to reduce class sizes for this situation or to use larger and better hardware IWBs. In order to make future studies more meaningful and effective, it is important to consider the opinions, proposals and expectations of teachers who are in service. 


\section{Kaynakça}

Akgün, F. (2013). Öğretmen adaylarının web pedagojik içerik bilgileri ve öğretmen özyeterlik algıları ile ilişkisi. Trakya Üniversitesi Eğitim Fakültesi Dergisi, 3(1).

Akyüz, H. İ., Pektaş, M., Kurnaz, M. A. \& Memiş, E. K. (2014). Akı1lı Tahta Kullanımlı Mikro Öğretim Uygulamalarının Fen Bilgisi Öğretmen Adaylarının Tbap'larına ve Akıllı Tahta Kullanıma Yönelik Algılarına Etkisi. Cumhuriyet International Journal of Education, 3(1).

Ali, H. \& Al-kaabi, R. (2012). Using An Interactive Whiteboard (IWB) to Increase Students' Engagement in English and Science Classes: The Case of Creativity Private School in Kingdom of Bahrain.

Al-Qirim, N. (2011). Determinants of interactive white board success in teaching in higher education institutions. Computers \& Education, 56(3), 827-838. doi: 10.1016/j.compedu.2010.10.024

Badilla Quintana, M. G. (2012). Teacher uses and perceptions of interactive whiteboard incorporation in Spanish Classrooms. Ubiquitous Learning, 4(2), 69-79.

Bakadam, E. \& Asiri, M. J. S. (2012). Teachers' Perceptions Regarding the Benefits of Using the Interactive Whiteboard (IWB): The Case of a Saudi Intermediate School. 12th International Educational Technology Conference - Ietc 2012, 64, 179-185. doi: 10.1016/j.sbspro.2012.11.021

Beauchamp, C., \& Thomas, L. (2009). Understanding teacher identity: An overview of issues in the literature and implications for teacher education. Cambridge Journal of Education, 39(2), 175-189.

Beauchamp, G. \& Kennewell, S. (2012). Transition in pedagogical orchestration using the interactive whiteboard. Education and Information Technologies, 18(2), 179191. doi: 10.1007/s10639-012-9230-z

Bidaki, M. Z. \& Mobasheri, N. (2013). Teachers' Views of the Effects of the Interactive White Board (IWB) on Teaching. In H. Uzunboylu \& F. Ozdamli (Eds.), 2nd World Conference on Educational Technology Research (Vol. 83, pp. 140-144).

Bruffaerts-Thomas, J. \& Bruffaerts, J. C. (2013). Haiti's digital education experiment: Interactive whiteboards in the classroom. Field Actions Science Report, 9(SPEC. ISSUE).

Büyüköztürk, Ş., Çakmak, E. K., Akgün, Ö. E., Karadeniz, Ş. \& Demirel, F. (2017). Bilimsel araştırma yöntemleri. Pegem Atıf İndeksi, 1-360.

Campbell, C. \& Martin, D. (2010). Interactive whiteboards and the first year experience: Integrating IWBs into pre-service teacher education. Australian Journal of Teacher Education, 35(6), 68-75.

Canbolat, N. (2011). Matematik öğretmen adaylarının teknolojik pedagojik alan bilgileri ile düşünme stilleri arasındaki ilişkinin incelenmesi. Selçuk Üniversitesi Eğitim Bilimleri Enstitüsü.

Coyle, Y., Yanez, L. \& Verdu, M. (2010). The impact of the interactive whiteboard on the teacher and children's language use in an ESL immersion classroom. System, 38(4), 614-625. doi: 10.1016/j.system.2010.10.002 
Çelik, H. C. \& Kahyaoğlu, M. (2007). İlköğretim öğretmen adaylarının teknolojiye yönelik tutumlarının kümeleme analizi. Türk Eğitim Bilimleri Dergisi, 5(4), 571586.

de Groot-Reuvekamp, M., Ros, A. \& van Boxtel, C. (2018). A successful professional development program in history: What matters? Teaching and Teacher Education, 75, 290-301. doi: https://doi.org/10.1016/j.tate.2018.07.005

Divaharan, S. \& Koh, J. H. L. (2010). Learning as students to become better teachers: Pre-service teachers' IWB learning experience. Australasian Journal of Educational Technology, 26(4), 553-570.

Emeagwali, O. L. \& Naghdipour, B. (2013). Exploring the Usage and User-Perception of Interactive White Boards in Higher Education in North Cyprus. 2nd World Conference on Educational Technology Research, 83, 272-276. doi: 10.1016/j.sbspro.2013.06.053

Gadbois, S. A. \& Haverstock, N. (2012). Middle Years Science Teachers Voice Their First Experiences With Interactive Whiteboard Technology. Canadian Journal of Science, Mathematics and Technology Education, 12(1), 121-135. doi: 10.1080/14926156.2012.649053

Glesne, C. (2013). Nitel araştırmaya giriş: Anı Yayıncılık.

Gregory, S. (2010). Enhancing student learning with interactive whiteboards: Perspective of teachers and students. Australian Educational Computing, 25(2), 3134.

Hammond, M., Reynolds, L. \& Ingram, J. (2011). How and why do student teachers use ICT? Journal of Computer Assisted Learning, 27(3), 191-203. doi: 10.1111/j.13652729.2010.00389.x

Ipek, I. \& Sözcü, O. F. (2016). Preferences and Attitudes for Using Interactive Whiteboards in Different Courses and Learning. European Journal of Contemporary Education, 15(1), 173-184. doi: 10.13187/ejced.2016.15.173

Jang, S. J. (2010). Integrating the interactive whiteboard and peer coaching to develop the TPACK of secondary science teachers. Computers \& Education, 55(4), 17441751. doi: 10.1016/j.compedu.2010.07.020

Jang, S. J. \& Tsai, M. F. (2012a). Exploring the TPACK of Taiwanese elementary mathematics and science teachers with respect to use of interactive whiteboards. Computers \& Education, 59(2), 327-338. doi: 10.1016/j.compedu.2012.02.003

Jang, S. J. \& Tsai, M. F. (2012b). Reasons for using or not using interactive whiteboards: Perspectives of Taiwanese elementary mathematics and science teachers. Australasian Journal of Educational Technology, 28(8), 1451-1465.

Lai, H. J. (2014). Adult learners' perceptions of the use of interactive whiteboards in university classrooms. New Educational Review, 36(2), 55-65.

Lopez, O. \& Krockover, C. (2014). Contextual factors relevant to elementary teachers using interactive whiteboards in mathematics classroom discourse. Journal of Interactive Learning Research, 25(3), 405-426.

MEB. (2017). Eğitimde FATİH Projesi Hakkında. Retrieved 11 July, 2017, from http://fatihprojesi.meb.gov.tr/proje-hakkinda/ 
Mishra, P. \& Koehler, M. J. (2006). Technological pedagogical content knowledge: A framework for teacher knowledge. Teachers college record, 108(6), 1017-1054. doi: DOI 10.1111/j.1467-9620.2006.00684.x

Öztürk, E. \& Horzum, M. B. (2011). Teknolojİk pedagojik içerik bilgisi ölçeği'nİn Türkçeye uyarlamasi. Ahi Evran Üniversitesi Kırşehir Eğitim Fakültesi Dergisi, 12(3).

Pamuk, S., Ülken, A. \& Dilek, N. Ş. (2012). Öğretmen Adaylarının Öğretimde Teknoloji Kullanım Yeterliliklerinin Teknolojik Pedagojik İçerik Bilgisi Kuramsal Perspektifinden İncelenmesi/The Investigation Of Preservice Teachers' Technology Integration Competencies From Technological Pedagogical Cont. Mustafa Kemal Üniversitesi Sosyal Bilimler Enstitüsü Dergisi, 9(17).

Patton, M. Q. (2014). Nitel araştırma ve değerlendirme yöntemleri. Çeviri Editörleri: Mesut Bütün \& Selçuk Beşir Demir), Ankara: Pegem Akademi.

Schmidt, D. A., Baran, E., Thompson, A. D., Mishra, P., Koehler, M. J. \& Shin, T. S. (2009). Technological pedagogical content knowledge (TPACK) the development and validation of an assessment instrument for preservice teachers. Journal of Research on Technology in Education, 42(2), 123-149.

Shulman, L. S. (1986). Those who understand: Knowledge growth in teaching. Educational researcher, 15(2), 4-14.

Sönmez, V. \& Alacapınar, F. G. (2011). Örneklendirilmiş bilimsel araştırma yöntemleri: Anı Yayıncılık.

Sumak, B. \& Sorgo, A. (2016). The acceptance and use of interactive whiteboards among teachers: Differences in UTAUT determinants between pre- and postadopters. Computers in Human Behavior, 64, 602-620. doi: 10.1016/j.chb.2016.07.037

Šumak, B., Pušnik, M., Heričko, M. \& Šorgo, A. (2017). Differences between prospective, existing, and former users of interactive whiteboards on external factors affecting their adoption, usage and abandonment. Computers in Human Behavior, 72, 733-756. doi: https://doi.org/10.1016/j.chb.2016.09.006

Tataroglu, B. \& Erduran, A. (2010). Examining students' attitudes and views towards usage an interactive whiteboard in mathematics lessons. Innovation and Creativity in Education, 2(2), 2533-2538. doi: 10.1016/j.sbspro.2010.03.368

Turel, Y. K. (2011). An interactive whiteboard student survey: Development, validity and reliability. Computers \& Education, 57(4), 2441-2450. doi: 10.1016/j.compedu.2011.07.005

Winzenried, A., Dalgarno, B. \& Tinkler, J. (2010). The interactive whiteboard: A transitional technology supporting diverse teaching practices. Australasian Journal of Educational Technology, 26(4), 534-552.

Wong, K. T., Teo, T. \& Goh, P. S. C. (2014). Development of the Interactive Whiteboard Acceptance Scale (IWBAS): An Initial Study. Educational Technology \& Society, 17(4), 268-277.

Wong, K. T., Teo, T. \& Goh, P. S. C. (2015). Understanding the intention to use interactive whiteboards: model development and testing. Interactive Learning Environments, 23(6), 731-747. doi: 10.1080/10494820.2013.806932 
Yildirim, A. \& Şimşek, H. (2005). Sosyal bilimlerde nitel araştırma yöntemleri. Ankara: Seçkin Yayıncılık.

Yüksel, İ. \& Adıgüzel, A. (2012). Öğretmenlerin öğretim teknolojileri entegrasyon becerilerinin değerlendirilmesi: Yeni pedagojik yaklaşımlar için nitel bir gereksinim analizi. Necatibey Ĕgitim Fakültesi Elektronik Fen ve Matematik Ĕ̈itimi Dergisi, 6(1). 